\title{
Highly-Efficient Purification of Native Polyhistidine-tagged Proteins by Multivalent NTA-modified Magnetic Nanoparticles
}

\author{
Jason S. Kim ${ }^{\dagger}$, C. Alexander Valencia ${ }^{\ddagger}$, Rihe Liu ${ }^{\ddagger},{ }^{*}$, and Wenbin Lin ${ }^{\dagger},{ }^{*}$ \\ $\dagger$ Department of Chemistry, University of North Carolina, Chapel Hill, NC 27599 \\ $\$$ School of Pharmacy and Carolina Center for Genome Sciences, University of North Carolina, Chapel Hill, \\ NC 27599
}

\begin{abstract}
A new bis-nitrilotriacetic acid (NTA) chelate with catechol anchor was synthesized and immobilized on superparamagnetic iron oxide nanoparticles. When loaded with Ni(II), these bis-NTAimmobilized nanoparticles were shown to bind polyhistidine (His $\times 6$-tagged) fusion proteins in their native, folded conformations that commercial microbeads failed to bind under identical conditions. Control experiments with a mono-NTA chelate immobilized on iron oxide nanoparticles indicate a similarly high affinity for His $\times 6$-tagged native proteins, suggesting that the high density of the monoNTA chelate presented by the nanoparticles allows the binding of the His $\times 6$-tag to more than one Ni-NTA moiety on the surface. This study shows that the multivalency strategy can be utilized to enhance the binding of His $\times 6$-tagged proteins in their native, folded conformations. We further demonstrated the selective purification of His $\times 6$-tagged proteins from crude cell lysates by using the $\mathrm{Ni}$ (II)-loaded iron oxide nanoparticles. The present platform is capable of efficient purification of His $\times 6$-tagged proteins that are expressed at low levels in mammalian cells. This work thus presents a novel nanoparticle-based high-capacity protein purification system with shorter incubation times, proportionally large washes, and significantly smaller elution volumes compared to commercially available microbeads.
\end{abstract}

\section{INTRODUCTION}

As we enter the proteomic era, there is an ever-increasing need for efficient protein purification techniques that allow for direct isolation of proteins from cell lysates.(1) Among many currently used protein purification strategies,(2) immobilized metal affinity chromatography (IMAC) has emerged as one of the most powerful techniques for the purification of recombinant proteins.(3) In the most common IMAC implementation, a His $\times 6$ tag that comprises of six consecutively placed histidine residues is incorporated into the $\mathrm{C}$ - or $\mathrm{N}$-terminus of a recombinant protein. The His $\times 6$ tag binds strongly to a divalent metal chelate such as the $\mathrm{Ni}$ (II) nitrilotriacetate complex (Ni-NTA) which is in turn immobilized on a resin. It is believed that four of the six coordination sites on the octahedral Ni(II) center are occupied by the NTA ligand and the remaining coordination sites are occupied by two of the six imidazole moieties in the His $\times 6$ tag. (4)

*Correspondence authors. (W.L.) Phone: (919)-962-6320. Fax: (919)-962-2388. E-mail: wlin@unc.edu. (R.L.) Phone: (919)-843

-3635. Fax: (919)-966-0204. E-mail: rliu@email.unc.edu..

Supporting Information Available. Detailed experimental procedures, data table, and figures areavailable free of charge via the Internet at http://pubs.acs.org. 
The IMAC strategy allows the purification of His $\times 6$-tagged proteins in one or two steps to achieve a moderate degree of purity. Moreover, the His $\times 6$ tag is relatively small and generally does not interfere with the native structure and function of the tagged protein. Since its discovery in late 1980s, Ni-NTA based IMAC has been widely used for purifying recombinant proteins, and many His $\times 6$-tagged proteins are now commercially available. While this strategy has proven to be largely successful, a significant percentage of recombinant proteins remain difficult to purify by IMAC.(5) Low protein expression is a key contributor to such difficulties as the target protein concentration may be less than $0.1 \%$ of the cleared crude lysate when overexpressed in $E$. coli, and much lower when overexpressed in mammalian cells. Numerous functionally active proteins can only be expressed in mammalian cells, which poses new challenges to protein purification techniques. The target protein structure may also add to purification difficulties by blocking the His $\times 6$-tag from the Ni-NTA moiety on the surface of microbeads. Consequently, commercial Ni-NTA resins cannot capture a large number of His $\times 6$-tagged proteins under native conditions. To overcome this problem, purification under denaturing conditions has been used to gain full access to the His $\times 6$-tag, but overall protein purification efficacy significantly decreases because of the unreliability and inefficiency of in vitro protein re-folding to their native functional conformations.

Significant efforts have been devoted to gaining a better understanding of the Ni-NTA/His $\times 6$ tag interactions and thus improving the IMAC protein purification efficiency over the past few years. The strength of the Ni-NTA/His $\times 6$-tag interaction was, for example, recently assessed using scanning force microscopic techniques.(6) Ebright et al. elegantly demonstrated enhanced binding of the His $\times 6$-tag to a bivalent Ni-NTA system over a monovalent Ni-NTA control using fluorescence anisotropy and fluorescence resonance energy transfer measurements.(7) Piehler et al. has further studied the enhanced affinity of multivalent $\mathrm{Ni}$ NTA-derived molecules toward the histidine tag in great detail. $(8,9,10)$ In the present work, we wish to design a superparamagnetic iron oxide immobilized bivalent Ni-NTA chelate system with the aim of improving IMAC purification of His $\times 6$-tagged proteins by strengthening the interactions between the His $\times 6-\operatorname{tag}$ and the bivalent Ni-NTA chelate. The bis-Ni-NTA-immobilized nanoparticles were shown to be capable of binding His $\times 6$-tagged proteins in their native, folded conformations that failed to bind commercial microbeads under identical conditions. We have demonstrated that the present system is superior to commercial magnetic beads in binding to His $\times 6$-tagged proteins and is useful for isolating target proteins that are overexpressed at low levels in the mammalian cells. Control experiments with a monoNTA chelate immobilized on iron oxide nanoparticles indicated a similarly high affinity for His $\times 6$-tagged proteins, suggesting that the very high density of the mono-NTA chelate presented by the nanoparticles allows the binding of the His $\times 6$-tag to more than one NTA moiety on the surface. Thus, this work demonstrates that the multivalency strategy can be utilized to enhance the binding of His $\times 6$-tagged proteins in their native, folded conformations.

\section{MATERIALS AND METHODS}

\section{General}

$\mathrm{N}_{\alpha}, \mathrm{N}_{\alpha}$-bis(carboxymethyl)-L-lysine was purchased from Fluka. 2-(3,4-Bis-benzyloxyphenyl)ethylamine-trifluoroacetate-salt (Bn-DA-TFA) and $\mathrm{N}_{\alpha}, \mathrm{N}_{\alpha}$-bis(carboxymethyl)-L-lysine tribenzyl ester-trifluoroacetate-salt (Bn-NTA-lys-TFA) were prepared from literature procedures. $(1,11)$ All other chemicals were purchased from Sigma-Aldrich and used as received unless otherwise noted. Carboxy-terminated magnetic microparticles were purchased from Bangs Laboratories, Inc. Purified recombinant His $\times 6$-endostatin (His $\times 6$-rmES) was purchased from Calbiochem. Recombinat human His $\times 6$-ubiquitin (His $\times 6-\mathrm{Ub})$ and mouse His $\times 6$-ubiquitin C-terminal hydrolase L-1 (His $\times 6-\mathrm{UCH}-\mathrm{L} 1$ ) were from Boston Biochem. ${ }^{1} \mathrm{H}$ and ${ }^{13} \mathrm{C}\left\{{ }^{1} \mathrm{H}\right\}$ NMR spectra were obtained on a Bruker $400 \mathrm{MHz}$ AVANCE or Bruker $400 \mathrm{MHz}$ 
DRX. Mass spectra were obtained from Voyager DE-Pro MALDI-MS or HP/Agilent LC/Iontrap MS in the Department of Chemistry at Duke University. Liquid scintillation counting experiments are performed on a Tri-Carb 2900TR Liquid Scintillation Analyzer. SDS-PAGE gels were quantified using the AlphaEaseFC program. Transmission Electron Microscopy (TEM) images were taken with a JEM-100CXII transmission electron microscope at $100 \mathrm{KV}$.

\section{Synthesis of dimethyl 5-(3,4-bis(benzyloxy)phenethylcarbamoyl)benzene-1,3-dioate (1)}

To a stirring solution of benzene-1,3,5-tricarbonyltrichloride $(1.7 \mathrm{~g}, 6.40 \mathrm{mmol})$ in dry $\mathrm{CH}_{2} \mathrm{Cl}_{2}(170 \mathrm{~mL})$ at $0^{\circ} \mathrm{C}$ was added Bn-DA-TFA $(0.536 \mathrm{~g}, 1.20 \mathrm{mmol})$ in dry $\mathrm{CH}_{2} \mathrm{Cl}_{2}(100$ $\mathrm{mL}$ ) dropwise over 5 hours. The solution was allowed to warm to room temperature. The solvent was removed under reduced pressure to produce a white residue. Methanol was added and stirred for a few hours. The excess methanol was removed under reduced pressure to produce a white solid. The product was isolated using flash column chromatography (ethyl acetate/hexanes, $\left.2: 3 \mathrm{v} / \mathrm{v} ; \mathrm{R}_{\mathrm{f}}=0.4\right)$. The solvents were removed under reduced pressure to yield a white solid of $1\left(0.225 \mathrm{~g}, 0.408 \mathrm{mmol}, 34.0 \%\right.$ yield). ${ }^{1} \mathrm{H} \mathrm{NMR}\left(400 \mathrm{MHz}, \mathrm{CDCl}_{3}\right): 8.75$ (s, $1 \mathrm{H}), 8.52(\mathrm{~s}, 2 \mathrm{H}), 7.40(\mathrm{~d}, 4 \mathrm{H}), 7.29(\mathrm{~m}, 6 \mathrm{H}), 6.90(\mathrm{~d}, 1 \mathrm{H}), 6.81(\mathrm{~s}, 1 \mathrm{H}), 6.72(\mathrm{~d}, 1 \mathrm{H}), 5.11(\mathrm{~s}$, 2H), $5.01(\mathrm{~s}, 2 \mathrm{H}), 3.92(\mathrm{~s}, 6 \mathrm{H}), 3.64(\mathrm{q}, 2 \mathrm{H}), 2.83(\mathrm{t}, 2 \mathrm{H}) ;{ }^{13} \mathrm{C} \mathrm{NMR}\left(\mathrm{CDCl}_{3}, 100 \mathrm{MHz}\right) \delta$ 165.4, 165.3, 149.0, 147.6, 137.2, 137.0, 135.4, 132.9, 132.0, 131.9, 130.9, 128.3, 127.7, 127.2, 121.5, 115.5, 115.3, 71.3, 71.2, 52.4, 41.4, 34.9, 31.5; MALDI-MS: $[\mathrm{M}+\mathrm{H}]^{+} \mathrm{m} / z$ 554.0 (calcd 554.6); $[\mathrm{M}+\mathrm{Na}]^{+}, \mathrm{m} / \mathrm{z} 577.2$ (calcd 576.6); [M+K $]^{+} \mathrm{m} / \mathrm{z} 592.8($ calcd 592.7).

\section{Synthesis of 5-(3,4-bis(benzyloxy)phenethylcarbamoyl)benzene-1,3-dioic acid (2)}

To a stirring solution of $\mathbf{1}(0.160,0.289 \mathrm{mmol})$ in acetone $(6 \mathrm{~mL})$ was added $1 \mathrm{~N} \mathrm{NaOH}(4 \mathrm{~mL})$. After 3 hours, complete deprotection was confirmed by TLC. The solution was acidified to $\mathrm{pH}$ 3 using $1 \mathrm{~N} \mathrm{HCl}$. The solvent was removed and the product was stirred in $\mathrm{H}_{2} \mathrm{O}$. The precipitate of 2 was collected by suction filtration and recrystallized in acetone $(0.145 \mathrm{~g}, 0.276 \mathrm{mmol}$, 95.5\% yield). ${ }^{1} \mathrm{H}$ NMR (400MHz, MeOD): 8.42 (s, $\left.1 \mathrm{H}\right), 8.21$ (s, 2H), 7.15-6.90 (m, 10H), $6.67(\mathrm{~s}, 1 \mathrm{H}), 6.62(\mathrm{~d}, 1 \mathrm{H}), 6.49(\mathrm{~d}, 1 \mathrm{H}), 4.73(\mathrm{~s}, 4 \mathrm{H}), 3.28(\mathrm{t}, 2 \mathrm{H}), 2.54(\mathrm{t}, 2 \mathrm{H}) ;{ }^{13} \mathrm{C}$ NMR (DMSO, $100 \mathrm{MHz}) \delta 166.4,164.6,148.3,146.8,137.5,137.4,135.5,132.7,132.2,132.0$, $131.8,128.4,127.8,127.7,127.6,127.5,121.2,115.2,114.8,70.3,70.2$, 41.1, 34.4; MALDIMS: $[\mathrm{M}+\mathrm{H}]^{+} \mathrm{m} / \mathrm{z} 525.9($ calcd 526.6).

\section{Synthesis of 5-(3,4-bis(benzyloxy)phenethylcarbamoyl)benzene-1,3-benzyl-NTA-lysine (3)}

The diacid $2(0.140 \mathrm{~g}, 0.266 \mathrm{mmol})$ was stirred in dry $\mathrm{CH}_{2} \mathrm{Cl}_{2}(13 \mathrm{~mL})$ to form a cloudy suspension. $0.40 \mathrm{~mL}$ of $\mathrm{SOCl}_{2}$ was slowly added and stirring continued at $50{ }^{\circ} \mathrm{C}$ for 6 hours to form a clear solution. The solvent was removed under reduced pressure to give the 5-(3,4bis(benzyloxy)phenethylcarbamoyl)-benzene-1,3-dioyl dichloride intermediate which was used without further purification.

To a stirring mixture of Bn-NTA-lys-TFA (0.408 g, $0.632 \mathrm{mmol})$, TEA $(0.5 \mathrm{~mL})$, and $\mathrm{CHCl}_{3}(5 \mathrm{~mL})$ was added a solution of 5-(3,4-bis(benzyloxy)phenethylcarbamoyl) benzene-1,3-dioyl dichloride in $\mathrm{CHCl}_{3}(10 \mathrm{~mL})$ dropwise at $0{ }^{\circ} \mathrm{C}$. The reaction was allowed to warm to room temperature and stir overnight. After removal of solvents under reduced pressure, column chromatography (ethyl acetate/hexanes, $3: 2 \mathrm{v} / \mathrm{v} ; \mathrm{R}_{\mathrm{f}}=0.5$ ) was used to isolate a pure white solid of $\mathbf{3}(0.281 \mathrm{~g}, 0.181 \mathrm{mmol}, 67.9 \%$ yield $) .{ }^{1} \mathrm{H} \mathrm{NMR}\left(\mathrm{CDCl}_{3}, 400 \mathrm{MHz}\right) \delta$ $8.33(\mathrm{~s}, 3 \mathrm{H}), 7.41-7.25(\mathrm{~m}, 35 \mathrm{H}), 6.95(\mathrm{t}), 6.86(\mathrm{~d}, 2 \mathrm{H}), 6.80(\mathrm{~s}, 2 \mathrm{H}), 6.69(\mathrm{~d}, 2 \mathrm{H}), 5.10(\mathrm{~s}$, $8 \mathrm{H}), 5.06(\mathrm{~s}, 2 \mathrm{H}), 4.98(\mathrm{~s}, 4 \mathrm{H}), 3.68(\mathrm{~s}, 4 \mathrm{H}), 3.59(\mathrm{t}, 4 \mathrm{H}), 3.46(\mathrm{t}, 1 \mathrm{H}), 3.32(\mathrm{t}, 2 \mathrm{H}) 2.75(\mathrm{t}, 4 \mathrm{H})$, $1,69-1.24(\mathrm{~m}, 6 \mathrm{H}) ;{ }^{13} \mathrm{C} \mathrm{NMR}\left(\mathrm{CDCl}_{3}, 100 \mathrm{MHz}\right) \delta 172.8,171.7,166.3,149.3,148.0,137.6$, $137.5,135.9,135.8,135.6,135.4,132.4,128.8,128.7,128.6,128.5,128.0,127.7,121.7,116.2$, 115.9, 71.6, 66.8, 66.7, 64.5, 53.1, 40.2, 35.4, 29.9, 28.5, 23.1; MALDI-MS: $[\mathrm{M}+\mathrm{H}]^{+} \mathrm{m} / \mathrm{z}$ 1556.3 (calcd 1555.8); [M+Na] $]^{+}, \mathrm{m} / \mathrm{z} 1577.5$ (calcd 1577.8); [M+K]+, m/z 1593.1 (calcd 1593.9). 


\section{Synthesis of 5-(3,4-bis(hydroxy)phenethylcarbamoyl)benzene-1,3-NTA-lysine (4)}

$3(0.043 \mathrm{~g}, 0.052 \mathrm{mmol})$ was dissolved in $1.5 \mathrm{~mL}$ of $\mathrm{CHCl}_{3}$ and $6 \mathrm{~mL}$ of $\mathrm{MeOH}$ and placed in a Parr flask with $15 \mathrm{mg} \mathrm{Pd} / \mathrm{C}(10 \%)$. The mixture was shaken in a Parr reactor for 24 hours under $\mathrm{H}_{2}(60 \mathrm{psi})$. Upon complete deprotection, the palladium catalyst was filtered off using Celite and solvent removed under reduced pressure. The product was purified by recrystallization in $\mathrm{MeOH} / \mathrm{CH}_{2} \mathrm{Cl}_{2}$ to give 4 in a quantitative yield. ${ }^{1} \mathrm{H} \mathrm{NMR}$ (MeOD, 400 $\mathrm{MHz}) \delta$; $8.29(\mathrm{~s}, 3 \mathrm{H}), 6.60(\mathrm{~s}, 1 \mathrm{H}), 6.59(\mathrm{~s}, 1 \mathrm{H}), 6.47(\mathrm{~d}, 2 \mathrm{H}), 3.71-3.21(\mathrm{~m}, 16 \mathrm{H}), 2.68(\mathrm{t}$, $2 \mathrm{H}), 1.63-1.45(\mathrm{~m}, 8 \mathrm{H}), 1.18(\mathrm{~m}, 4 \mathrm{H}) ;{ }^{13} \mathrm{C} \mathrm{NMR}\left(\mathrm{CDCl}_{3}, 100 \mathrm{MHz}\right) \delta ; 174.1,173.0,168.6$, 146.7, 144.7, 136.6, 132.0, 130.0, 121.1, 117.0, 116.4, 66.9, 54.3, 43.1, 40.7, 35.9, 29.8, 29.8, 24.4; MALDI-MS: $[\mathrm{M}]^{+}, \mathrm{m} / z 833$ (calcd 833.8); [M+Na] $]^{+}, \mathrm{m} / \mathrm{z} 856$ (calcd 856.8).

\section{Synthesis of methyl 3,5-bis(3,4-bis(benzyloxy)phenethylcarbamoyl)benzoate (5)}

To a stirring solution of benzene-1,3,5-tricarbonyltrichloride $(0.320 \mathrm{~g}, 1.20 \mathrm{mmol})$ in dry $\mathrm{CH}_{2} \mathrm{Cl}_{2}(170 \mathrm{~mL})$ at $0{ }^{\circ} \mathrm{C}$ was added Bn-DA-TFA $(0.536 \mathrm{~g}, 1.20 \mathrm{mmol})$ in dry $\mathrm{CH}_{2} \mathrm{Cl}_{2}(100$ $\mathrm{mL}$ ) dropwise over 5 hours. The solution was allowed to warm to room temperature. The solvent was removed under reduced pressure to produce a white residue. Methanol was added and allowed to stir for a few hours. The excess methanol was removed under reduced pressure to produce a white solid. The product was isolated using silica flash column chromatography (ethyl acetate/hexanes, $1: 1 \mathrm{v} / \mathrm{v} ; \mathrm{R}_{\mathrm{f}}=0.4$ ). The solvents were removed under reduced pressure to yield a white solid of $\mathbf{5}(0.298 \mathrm{~g}, 0.349 \mathrm{mmol}, 29.0 \%$ yield $) .{ }^{1} \mathrm{H} \mathrm{NMR}\left(\mathrm{CDCl}_{3}, 400 \mathrm{MHz}\right)$ $\delta 8.44(\mathrm{~s}, 2 \mathrm{H}), 8.28(\mathrm{~s}, 1 \mathrm{H}), 7.45-7.25(\mathrm{~m}, 20 \mathrm{H}), 6.88(\mathrm{~d}, 2 \mathrm{H}), 6.81(\mathrm{~s}, 2 \mathrm{H}), 6.71(\mathrm{~d}, 2 \mathrm{H}), 6.56$ $(\mathrm{t}, 2 \mathrm{H}), 5.10,(\mathrm{~s}, 8 \mathrm{H}), 3.88(\mathrm{~s}, 3 \mathrm{H}), 3.60(\mathrm{q}, 4 \mathrm{H}), 2.80(\mathrm{t}, 4 \mathrm{H}) ;{ }^{13} \mathrm{C} \mathrm{NMR}\left(\mathrm{CDCl}_{3}, 100 \mathrm{MHz}\right)$ $\delta$ 165.6, 165.3 148.7, 147.4, 136.9, 136.8, 135.1, 131.9, 130.5, 130.3, 129.6, 128.2, 127.6, 127.2, 127.1, 121.4, 115.4, 115.0, 71.1, 52.2, 41.3, 34.7; MALDI-MS: $[\mathrm{M}+\mathrm{Na}]^{+}, \mathrm{m} / z$ 877.0 (calcd 878.0); [M+K $]^{+}, \mathrm{m} / \mathrm{z} 893.0$ (calcd 894.1).

\section{Synthesis of 3,5-bis(3,4-bis(benzyloxy)phenethylcarbamoyl)benzoic acid (6)}

$5(0.250 \mathrm{~g}, 0.292 \mathrm{mmol})$ was stirred in a solution of $3 \mathrm{~mL}$ of acetone and $1 \mathrm{~mL}$ of $1 \mathrm{M} \mathrm{NaOH}$ overnight. The solution was acidified to $\mathrm{pH} 3$ using $1 \mathrm{~N} \mathrm{HCl}$, added dropwise. The solvent was removed and the product was stirred in $\mathrm{H}_{2} \mathrm{O}$. The precipitate was collected by vacuum filtration to give 6 in quantitative yield. ${ }^{1} \mathrm{H}$ NMR $(\mathrm{MeOD}, 400 \mathrm{MHz}) \delta 8.53(\mathrm{~s}, 2 \mathrm{H}), 8.37(\mathrm{~s}, 1 \mathrm{H}), 7.40$ $-7.20(\mathrm{~m}, 20 \mathrm{H}), 6.93(\mathrm{~s}, 2 \mathrm{H}), 6.91(\mathrm{~s}, 2 \mathrm{H}), 6.76(\mathrm{~d}, 2 \mathrm{H}), 5.03(\mathrm{~s}, 8 \mathrm{H}), 3.54(\mathrm{t}, 4 \mathrm{H}), 2.81(\mathrm{t}$, $4 \mathrm{H}) ;{ }^{13} \mathrm{C} \mathrm{NMR}\left(\mathrm{CDCl}_{3}, 100 \mathrm{MHz}\right) \delta 169.2,164.9,150.4,148.9,138.9,138.8,136.3,134.3$, $131.9,129.8,129.5,128.9$ 128.8, 123.1, 117.2, 116.9, 72.7, 72.5, 42.8, 37.0; MALDI-MS: [M $+\mathrm{Na}]^{+}, \mathrm{m} / 2863.4($ calcd 864.0).

\section{Synthesis of benzyl 6-( $\mathrm{N}^{3}, \mathrm{~N}^{5}$-bis(3,4-bis(benzyloxy)phenethyl)benzene-1,3,5- tricarboxamido)-2-(bis(((benzyloxy)carbonyl)methyl)amino)hexanoate (7)}

A mixture of Bn-NTA-lys-TFA (0.060 g, $0.071 \mathrm{mmol}), 6$ (0.075 g, $0.142 \mathrm{mmol})$, and HOBt $(0.010 \mathrm{~g}, 0.074 \mathrm{mmol})$ was stirred in $3 \mathrm{~mL}$ anhydrous DMF for 5 minutes.

Dicyclohexylcarbodiimide $(0.015 \mathrm{~g}, 0.073 \mathrm{mmol})$ was added and the mixture was allowed to stir overnight. The solvents were removed under reduced pressure. The product 7 was isolated with silica gel flash column chromatography (ethyl acetate/hexanes, $3 / 2 \mathrm{v} / \mathrm{v} ; \mathrm{R}_{\mathrm{f}}=0.4$ ). Yield: $0.094 \mathrm{~g}(97.7 \%) .{ }^{1} \mathrm{H} \mathrm{NMR}\left(\mathrm{CDCl}_{3}, 400 \mathrm{MHz}\right) \delta 8.43(\mathrm{~s}, 1 \mathrm{H}), 8.41(\mathrm{~s}, 2 \mathrm{H}), 7.50-7.26(\mathrm{~m}, 40 \mathrm{H})$, $7.04(\mathrm{~s}, 3 \mathrm{H}), 6.87(\mathrm{~s}, 1 \mathrm{H}), 6.85(\mathrm{~d}, 1 \mathrm{H}), 6.72(\mathrm{~d}, 1 \mathrm{H}), 5.12(\mathrm{~s}, 8 \mathrm{H}), 5.07(\mathrm{~s}, 8 \mathrm{H}), 3.74(\mathrm{~s}, 8 \mathrm{H})$, 3.59 (t, 2H), $3.51(\mathrm{t}, 2 \mathrm{H}), 3.35(\mathrm{t}, 4 \mathrm{H}), 2.79(\mathrm{t}, 2 \mathrm{H}), 1.75-1.28(\mathrm{~m}, 12 \mathrm{H}) ;{ }^{13} \mathrm{C} \mathrm{NMR}\left(\mathrm{CDCl}_{3}\right.$, $100 \mathrm{MHz}) \delta 172.5,171.5,165.9,148.9,147.6,137.2,137.1,135.3,132.0,128.5,128.4,128.3$, $128.2,128.1,127.7,127.4,127.3,121.5,115.7,115.2,71.3,66.5,66.4,64.0,52.8,41.5,39.9$, 35.0, 27.9, 25.5, 24.8; MALDI-MS: $[\mathrm{M}+\mathrm{H}]^{+}, \mathrm{m} / \mathrm{z} 1356.4(\mathrm{calcd} 1355.6)$; $[\mathrm{M}+\mathrm{Na}]^{+}, \mathrm{m} / \mathrm{z} 1378.0$ (calcd 1378.6); $[\mathrm{M}+\mathrm{K}]^{+}, \mathrm{m} / \mathrm{z} 1393.9$ (calcd 1394.7). 


\section{Synthesis of 6-( $N^{3}, N^{5}$-bis(3,4-dihydroxyphenethyl)benzene-1,3,5-tricarboxamido)-2-(bis (carboxymethyl)amino)hexanoic acid (8)}

To a solution $7(0.094 \mathrm{~g}, 0.069 \mathrm{mmol})$ in of $5 \mathrm{~mL}$ of $\mathrm{MeOH}$ and $10 \mathrm{~mL}$ of $\mathrm{CHCl}_{3}$ was added $20 \mathrm{mg} \mathrm{Pd} / \mathrm{C}(10 \%)$. The mixture was placed in a Parr reactor bottle and rocked for 24 hours at $60 \mathrm{psi}_{2}$. Upon complete deprotection, the catalyst was filtered off using Celite and the solvents were removed under reduced pressure. 8 was purified by recrystallization in $\mathrm{MeOH} /$ $\mathrm{CH}_{2} \mathrm{Cl}_{2}$ in a quantitative yield. ${ }^{1} \mathrm{H}$ NMR (MeOD, $\left.400 \mathrm{MHz}\right) \delta 8.34(\mathrm{~s}, 3 \mathrm{H}), 6.69(\mathrm{~s}, 2 \mathrm{H}), 6.67$ $(\mathrm{s}, 2 \mathrm{H}), 6.56(\mathrm{~d}, 2 \mathrm{H}), 3.64(\mathrm{t}, 4 \mathrm{H}), 3.60(\mathrm{t}, 1 \mathrm{H}), 3.33(\mathrm{~s}, 4 \mathrm{H}), 3.29(\mathrm{t}, 2 \mathrm{H}), 2.77(\mathrm{t}, 4 \mathrm{H}), 1.90$ $-1.50(\mathrm{~m}, 4 \mathrm{H}), 1.27(\mathrm{p}, 2 \mathrm{H}) ;{ }^{13} \mathrm{C} \mathrm{NMR}\left(\mathrm{CDCl}_{3}, 100 \mathrm{MHz}\right) \delta ; 175.3,174.1,168.5,146.1,144.7$, 136.6, 132.0, 129.4, 121.1, 117.0, 116.4, 68.2, 55.1, 43.1, 40.3, 35.9, 26.4, 25.9, 23.6. MALDIMS: $[\mathrm{M}+\mathrm{H}]^{+}, \mathrm{m} / \mathrm{z} 724.8\left(\right.$ calcd 725.7); $[\mathrm{M}+\mathrm{Na}]^{+}, \mathrm{m} / \mathrm{z} 746.8($ calcd 747.7$)$.

\section{Surface modification of iron oxide nanoparticles with bis-NTA-derived Ni(II) chelate and mono-NTA-derived Ni(II) chelate}

. The ligand $4(0.5 \mathrm{~mL}$ of a $10 \mathrm{mg} / \mathrm{mL} \mathrm{MeOH}$ solution $)$ was placed in $1.25 \mathrm{~mL}$ distilled water. To this aqueous solution was added $1 \mathrm{~mL}$ of iron oxide nanoparticles in $n$-hexanes $(16.3 \mathrm{mg} /$ $\mathrm{mL}$ ). The two layers were sonicated for 1 hour, and repeatedly washed with $n$-hexanes, then methanol until the nanoparticles were readily dispersed in distilled water. Using a magnet, the nanoparticles were collected and placed in $2 \mathrm{~mL}$ of distilled water. The bis-NTA-pendant ligand-immobilized nanoparticles $(0.5 \mathrm{~mL})$ were placed in $2 \mathrm{M} \mathrm{NiCl}_{2}$ solution and sonicated for 1 hour. The $\mathrm{Ni}$ (II)-loaded nanoparticles were stored in the $\mathrm{NiCl}_{2}$ solution before use. Iron oxide nanoparticle modified with mono-NTA Ni(II)-loaded nanoparticles were similarly prepared.

\section{Preparation of $\mathrm{Ni}(\mathrm{II})$-loaded magnetic microparticles}

An aliquot of $0.5 \mathrm{~mL}$ ( $2.4 \mu \mathrm{mol}$ carboxyl) BioMag Carboxyl magnetic iron oxide microparticles $(\sim 1.5 \mu \mathrm{m}$ mean diameter, $\sim 20 \mathrm{mg} / \mathrm{mL}$ particle concentration, $\sim 4.8 \mu \mathrm{mol} / \mathrm{mL}$ carboxy-surface titration) was washed with distilled water $(3 \times 500 \mu \mathrm{L})$, then with acetone $(3 \times 500 \mu \mathrm{L})$. Aliquots of $N$-hydroxysuccinimide (NHS) $(25 \mu \mathrm{L}, 30 \mathrm{mg} / \mathrm{mL}$ acetone) and dicyclohexylcarbodiimide $(50 \mu \mathrm{L}, 50 \mathrm{mg} / \mathrm{mL}$ acetone) were added and incubated overnight. The NHS-activated particles were washed with acetone and used without further purification.

A $240 \mu \mathrm{M}$ solution of $\mathrm{N}_{\alpha}, \mathrm{N}_{\alpha}$-bis(carboxymethyl)-L-lysine was prepared by dissolving 0.629 $\mathrm{mg} \mathrm{N}_{\alpha}, \mathrm{N}_{\alpha}$-bis(carboxymethyl)-L-lysine in $35 \mu \mathrm{L}$ of triethylamine, $500 \mu \mathrm{L}$ of acetone, and 500 $\mu \mathrm{L}$ of distilled water. The NHS-activated microparticles were washed with distilled water, then placed in $100 \mu \mathrm{L}$ of the $\mathrm{N}_{\alpha}, \mathrm{N}_{\alpha}$-bis(carboxymethyl)-L-lysine solution. After overnight incubation, the particles were washed with distilled water. The particles were placed in a $1 \mathrm{M}$ $\mathrm{NiCl}_{2}$ solution for 1 hour before use.

\section{Isolation of recombinant mouse His $\times 6$-Endostatin (His $\times 6-$ rmES) with $\mathrm{Ni}(\mathrm{II})$-loaded nanoparticles}

The Ni(II)-loaded nanoparticles $(7-10 \mu \mathrm{L} ; 16.3 \mathrm{mg} / \mathrm{mL})$ were washed in distilled water $(3 \times 50$ $\mu \mathrm{L})$ and a binding buffer ( $3 \times 50 \mu \mathrm{L} ; 50 \mathrm{mM}$ phosphate buffer system, $300 \mathrm{mM} \mathrm{NaCl}, 10 \mathrm{mM}$ imidazole, $\mathrm{pH}$ 8.0). The washed nanoparticles were incubated with $10 \mu \mathrm{g}$ of His $\times 6-\mathrm{rmES}$ in $40 \mu \mathrm{L}$ of binding buffer for $5-60$ minutes at $4{ }^{\circ} \mathrm{C}$. Using a centrifuge and magnet, the supernatant was collected and nanoparticles washed in $50 \mu \mathrm{L}$ aliquots of binding buffer (FT: Flow Through, W1: Wash 1, W2: Wash 2, W3: Wash 3). After the third wash, $50 \mu \mathrm{L}$ of the elution buffer (50 mM phosphate buffer system, $300 \mathrm{mM} \mathrm{NaCl}, 250 \mathrm{mM}$ imidazole, $\mathrm{pH}$ 8.0) was added and the mixture tumbled for 10 minutes at $4{ }^{\circ} \mathrm{C}$. The eluents were similarly collected by centrifugation and magnetic immobilization (E1: Elution 1, E2: Elution 2). Non-specifically bound protein was released from the nanoparticles by boiling at $95{ }^{\circ} \mathrm{C}$ for 4 minutes in a 
Laemmli SDS-PAGE gel loading buffer. The volumes of the aliquots were reduced in a Speedvac before loading to an SDS-PAGE (12.5\%, 180V, $50 \mathrm{~min})$. After separation, the SDSPAGE gel was stained in a Coomassie Blue solution $(0.1 \%$ Coomassie blue, $10 \%$ acetic acid, $40 \%$ methanol) overnight. Recombinant human His $\times 6$-ubiquitin (His $\times 6-U b$ ), and recombinant mouse His $\times 6$-ubiquitin C-terminal hydrolase L-1 (His $\times 6-\mathrm{UCH}-\mathrm{L} 1)$ were isolated with $\mathrm{Ni}(\mathrm{II})$ loaded nanoparticles in the same fashion. Protein isolation by commercial magnetic agarose beads was performed according to the manufacturer's instructions (Qiagen).

\section{Isolation of His $\times 6-$ rmES by $\mathrm{Ni}(\mathrm{II})$-loaded microparticles}

The Ni(II)-loaded microparticles $(10 \mu \mathrm{L}, 20 \mathrm{mg} / \mathrm{mL})$ were washed in distilled water $(3 \times 50 \mu \mathrm{L})$ and binding buffer $(3 \times 50 \mu \mathrm{L})$. The washed microparticles were incubated with $10 \mu \mathrm{g}$ of His $\times 6$ rmES in $40 \mu \mathrm{L}$ of binding buffer for 60 minutes at $4{ }^{\circ} \mathrm{C}$. The beads were washed and the bound protein eluted similarly. All the fractions were loaded to an SDS-PAGE for analysis as previously described.

\section{Expression of $\left[{ }^{35} \mathrm{~S}\right]-$ methionine-labeled His $\times 6$-GMAP-210}

The gene coding a $70 \mathrm{kDa}$ fragment of GMAP-210 (Golgi-associated microtubule-binding protein) was PCR-amplified from a human total RNA library (Stratagene). After introducing the T7 promoter and TMV 5'-UTR by second PCR, the cDNA was used as template for a coupled in vitro transcription/translation (TNT) reaction in the presence of $10 \mu \mathrm{Ci}\left[{ }^{35} \mathrm{~S}\right]-$ methionine (Perkin-Elmer) in a total volume of $25 \mu \mathrm{L}$ for 90 minutes at $30^{\circ} \mathrm{C}$. Protein synthesis was confirmed by SDS-PAGE and autoradiography. The protein was stored at $-80^{\circ} \mathrm{C}$ until used.

\section{Isolation of [ $\left.{ }^{35} \mathrm{~S}\right]-$ methionine-labeled His $\times 6$-GMAP-210 with $\mathrm{Ni}(\mathrm{II})$-loaded nanoparticles}

The $\mathrm{Ni}(\mathrm{II})$-loaded nanoparticles $(10 \mu \mathrm{L} ; 16.3 \mathrm{mg} / \mathrm{mL})$ were washed in distilled water $(3 \times 50$ $\mu \mathrm{L})$ and binding buffer $(3 \times 50 \mu \mathrm{L})$. The washed nanoparticles were incubated with $5 \mu \mathrm{L}$ of TNT reaction mixture in $100 \mu \mathrm{L}$ of binding buffer for 60 minutes at $4{ }^{\circ} \mathrm{C}$. The nanoparticles were washed and the bound protein eluted according to the procedures detailed above. All the fractions including the remaining nanoparticles were transferred to scintillation vials for radioactivity measurements using a liquid scintillation counter. Protein isolation using commercial magnetic agarose beads (Qiagen) was performed according to the manufacturer's instructions, and scintillation counts were measured as mentioned above.

\section{Expression and purification of His×6-UGT from 293T cells using nanoparticles}

The cDNA corresponding to the open reading frame of $C$. elegans UGT was amplified from a C. elegans cDNA library (Invitrogen) using high fidelity Platinum Pfx DNA polymerase (Invitrogen) and sequence-specific primers with CACC at the 5' end of the forward primer. The full-length cDNA was gel purified and subcloned into the pcDNA3.1D/V5-His TOPO vector (Invitrogen) according to the manufacturer's instructions. The resulting gene-containing plasmid was confirmed by PCR and sequence analysis.

293T cells were cultured in Dulbecco's Minimal Essential Media (DMEM, Gibco) supplemented with $10 \%$ Fetal Bovine Serum (FBS, Sigma), $1 \%$ L-glutamate (Gibco), and $1 \%$ Penicillin/Streptomycin. Cell culture was maintained at $37{ }^{\circ} \mathrm{C}$ with $5 \% \mathrm{CO}_{2}$. On the day of transfection, the pre-formed UGT plasmid DNA-Lipofectamine complex $(500 \mu \mathrm{L})$ was added directly to each well. Cells were incubated at $37{ }^{\circ} \mathrm{C}$ in $5 \% \mathrm{CO}_{2}$ for 4 hours. Afterwards, the media was changed and $2 \mathrm{~mL}$ of fresh DMEM (with $10 \%$ FBS and $1 \%$ L-glutamate) was added. After incubation at $37{ }^{\circ} \mathrm{C}$ in a $5 \% \mathrm{CO}_{2}$ incubator for a total of 24 hours to allow protein expression, cells were harvested and lysed using a commercial extraction buffer (Biovision). Intact cells were removed by centrifugation and the supernatants were cleared at $21,000 \times \mathrm{g}$ for 
15 minutes at $4{ }^{\circ} \mathrm{C}$. Levels of protein expression were assessed by separation on SDS-PAGE gels, followed by Western blotting onto nitrocellulose membranes (Amersham Pharmacia), and probing with anti-V5 antibody (Invitrogen). The lysates that were prepared were used for binding studies.

To purify the His $\times 6$-UGT expressed in $293 \mathrm{~T}$ cells, the pre-washed, Ni(II)-loaded nanoparticles $(10 \mu \mathrm{L} ; 16.3 \mathrm{mg} / \mathrm{mL})$ were incubated with $50 \mu \mathrm{L}$ of cleared crude cell lysate $(\sim 4 \mu \mathrm{g} / \mu \mathrm{L}$ total protein) in $50 \mu \mathrm{L}$ of binding buffer for 15 minutes at $4{ }^{\circ} \mathrm{C}$. After washing nanoparticles three times using $50 \mu \mathrm{L}$ of binding buffer, the bound proteins were eluted using $15 \mu \mathrm{L}$ of elution buffer. Aliquots of each fraction were loaded to an SDS-PAGE for separation. The protein was detected by Coomassie blue staining.

\section{RESULTS AND DISCUSSION}

\section{Surface Modification of Iron Oxide Nanoparticles with Bis-NTA and Mono-NTA Ni(II) Chelates}

The iron oxide magnetic nanoparticles were synthesized using protocols previously described. $(12,13,14)$ The nanoparticles were washed in ethanol and transferred into $n$-hexanes and used without further purification. The concentration of the nanoparticles was estimated based on the dry mass after the removal of the solvents. Iron oxide nanoparticles prepared by different routes gave similar results for protein binding and purification experiments.

Although a number of functional groups have been immobilized on iron oxide nanoparticles, their binding strength and their ease of surface immobilization vary significantly. Since $\mathrm{Xu}$ and co-workers recently demonstrated the efficient immobilization of dopamine derivatives on iron oxide nanoparticles,(15) we have decided to use this strategy to immobilize bis-NTA $\mathrm{Ni}(\mathrm{II})$ chelate for protein purifications. The new bis-NTA ligand with a catechol group (4) was synthesized according to Scheme 1. Compound 4 was synthesized in $22 \%$ overall yield in 4 steps starting from known benzyl-protected dopamine trifluoroacetate salt and benzene-1,3,5tricarbonyltrichloride. New compounds $\mathbf{1 - 4}$ were characterized by ${ }^{1} \mathrm{H}$ and ${ }^{13} \mathrm{C}\left\{{ }^{1} \mathrm{H}\right\} \mathrm{NMR}$ spectroscopy and mass spectrometry.

In order to determine the effects of multivalency on protein binding, we have also prepared a new mono-NTA ligand with two catechol groups $(\mathbf{8})$ by using a 1:1 ratio of dopamine hydrochloride and benzene-1,3,5-tricarbonyltrichloride as shown in Scheme 2. Compound $\mathbf{8}$ was synthesized in an overall yield of $28 \%$ in 4 steps. New compounds 5-8 were characterized by ${ }^{1} \mathrm{H}$ and ${ }^{13} \mathrm{C}\left\{{ }^{1} \mathrm{H}\right\}$ NMR spectroscopy and mass spectrometry.

Surface modification of iron oxide nanoparticles with new NTA-derived ligands was accomplished by simply stirring a biphasic mixture of the ligand in water and iron oxide nanoparticles in hexanes. The NTA-ligand-immobilized nanoparticles were charged with $\mathrm{Ni}$ (II) ions by ultrasonic mixing in $2 \mathrm{M} \mathrm{NiCl}_{2}$. The iron oxide nanoparticles with different coatings were characterized by transmission electron microscopy (TEM). TEM images of $\sim 10 \mathrm{~nm}$ monodisperse iron oxide nanoparticles (prepared by thermal decomposition) before and after surface modifications illustrate the retention of nanoparticle size and shape, and monodispersity throughout monovalent and bivalent NTA-ligand surface modification and Ni (II)-loading. Slight aggregation of $\mathrm{Ni}$ (II)-loaded nanoparticles was however observed in the TEM images (Figure 1).

\section{Binding of His $\times 6$-tagged Proteins Labeled with $\left[{ }^{35}\right.$ S $]$-Methionine}

Immobilization of proteins onto the nanoparticles and subsequent elution were initially demonstrated with His $\times 6$-tagged, $\left[{ }^{35}\right.$ S $]$-methionine-labeled GMAP-210 protein synthesized via coupled in vitro transcription and translation (Scheme 3). In a typical binding-elution experiment, the direct lysate (DL) signal is equal to the sum of the flow through (FT), washes 
(W1, W2, W3), elutions (E1, E2), and residual resin signals. The signal from each fraction was measured using liquid scintillation counting.

Since only a small percentage of $\left[{ }^{35} \mathrm{~S}\right]$-methionine was incorporated into the recombinant protein in the TNT reaction, a majority of the radioactivity in both the commercial beads and nanoparticle systems came from unbound free $\left[{ }^{35} \mathrm{~S}\right]$-methionine in the FT (Figure 2 and Table S1). Following the removal of FT, the resin was washed three times until the background was low, before elution by imidazole. This scintillation counting assay demonstrates that the NTAmodified nanoparticles can specifically capture His $\times 6$-tagged proteins followed by efficient elution with imidazole. We also examined the relative protein binding capacity of nanoparticles as compared to the commercial beads. It was found that the $10 \mu \mathrm{L}(0.32 \% \mathrm{v} / \mathrm{v}$ suspension, assuming $\mathrm{Fe}_{3} \mathrm{O}_{4}$ density of $\left.5.15 \mathrm{~g} / \mathrm{cm}^{3}\right)$ of nanoparticle $(16.3 \mathrm{mg} / \mathrm{mL})$ had a similar binding capacity to $10 \mu \mathrm{L}$ ( $5 \% \mathrm{v} / \mathrm{v}$ suspension) of commercial magnetic agarose beads. It appears that the unoptimized nanoparticles used in this work have higher residual radioactivity after elutions when compared to the commercial beads, presumably due to relatively strong nonspecific binding. This result was within expectation, since the commercial beads were coated with agarose, which has low non-specific binding to proteins. We think that the non-specific binding of the nanoparticle could be minimized if its surface is modified with hydrophilic molecules such as PEG that are known to resist nonspecific protein binding.(16)

\section{Binding of Overexpressed His $\times 6$-tagged Proteins}

We next carried out protein binding studies of several commercially available recombinant His $\times 6$-tagged proteins. One of the major problems in using Ni-NTA in protein purification is that numerous His $\times 6$-tagged proteins can only be purified under denaturing conditions. Consequently, a complicated refolding process is needed that often results in low yield of the active protein. In this work, we focus on examining whether the NTA-modified nanoparticles can be used under native conditions to purify His $\times 6$-tagged proteins that require denaturing conditions when commercial NTA beads are used. We used recombinant murine His $\times 6$ endostatin as an example. Endostatin is a potent angiogenesis inhibitor that has shown therapeutic suppression of tumor-induced angiogenesis in mice implanted with tumors.(17) O'Reilly et al. reported that recombinant murine endostatin with His $\times 6$ tag could be expressed in E. coli as insoluble inclusion bodies and purified using Ni-NTA resin under denaturing conditions. Endostatin thus purified underwent an inefficient refolding process before it could be used in xenograft mouse studies. We found that the already folded endostatin could not be captured when commercial Ni(II)-NTA beads were used. As shown in Figure 3, approximately 90\% of His $\times 6$-rmES was present in the FT, and almost no protein was detected in the elutions, indicating that commercial beads failed to capture His $\times 6-$-rmES under native conditions. Significantly, Ni(II)-loaded nanoparticles readily bound His $\times 6$-rmES without the use of denaturing conditions. A $10 \mu \mathrm{L}$ volume of $\mathrm{Ni}(\mathrm{II})$-loaded nanoparticles $(163 \mu \mathrm{g})$ is found to have a binding capacity of $5.6 \mu \mathrm{g}$ under unoptimized conditions. The His $\times 6$-rmES was readily eluted by imidazole and was shown to be biologically active in inducing apoptosis in cow pulmonary artery endothelial cells (Figure S1)(18). Confocal microscopic images showed characteristic apoptotic rings for the cow pulmonary artery endothelial cells after annexin- $\mathrm{V}$ $\mathrm{PE}$ staining. This result indicates that milligrams of a biologically active native protein can be purified using approximately $30 \mathrm{mg}$ of $\mathrm{Ni}$ (II)-loaded nanoparticles. We have also successfully recycled and reused the modified nanoparticles in His $\times 6$-rmES binding without $\mathrm{Ni}$ (II) reloading. The recycled nanoparticle appears to have a similar binding capacity to the pristine sample based on SDS-PAGE analysis (Figure S2).

We also compared the binding of other His $\times 6$-tagged proteins that do not require denaturing conditions for Ni-NTA based purifications. Ubiquitin is a protein found throughout all eukaryotic cells and plays key roles in highly specific protein degradation. The small His $\times 6-$ 
tagged ubiquitin $(9.3 \mathrm{kDa})$ is expected to have an affinity for both the commercial beads as well as the surface modified nanoparticles. SDS-PAGE analysis confirms the affinity of the commercial beads and the Ni(II)-loaded nanoparticle (Table 1 and Figure S3). Densitometry analysis shows the binding capacity of $20 \mu \mathrm{L}$ ( $5 \% \mathrm{v} / \mathrm{v}$ suspension) of commercial beads is 1.1 $\mu \mathrm{g}$ His $\times 6-\mathrm{Ub}$, while that of $10 \mu \mathrm{L}(0.32 \% \mathrm{v} / \mathrm{v}$ suspension $)$ of bis-NTA-Ni(II)-loaded nanoparticle is $2.3 \mu \mathrm{g}$. In comparing the binding of $10 \mu \mathrm{L}(0.32 \% \mathrm{v} / \mathrm{v}$ suspension $)$ of nanoparticle for His $\times 6-\mathrm{rmES}(21.3 \mathrm{kDa}, 5.6 \mu \mathrm{g})$ and $6 \times \mathrm{His}-\mathrm{Ub}(9.3 \mathrm{kDa}, 2.3 \mu \mathrm{g})$, it is estimated that the binding capacity of the $\mathrm{Ni}$ (II)-loaded nanoparticles is approximate 25 pmol of proteins/ $\mu \mathrm{L}$.

Binding studies on His $\times 6-\mathrm{UCH}-\mathrm{L} 1(\sim 25 \mathrm{kDa})$ were also used to demonstrate the nanoparticle's ability to capture His $\times 6$-enzymes (Table 1 and Figure S4). Binding capacities of $40 \mu \mathrm{L} \mathrm{(5 \%} \mathrm{v/}$ $\mathrm{v}$ suspension $)$ of commercial beads and $10 \mu \mathrm{L}(0.32 \% \mathrm{v} / \mathrm{v}$ suspension $)$ of nanoparticle are 0.06 $\mu \mathrm{g}$ and $3.48 \mu \mathrm{g}$ His $\times 6-\mathrm{UCH}-\mathrm{L} 1$, respectively. One major concern in NTA microbeads based protein purification is the large elution volume that requires additional concentration steps before being used in the subsequent experiments. While lyophilization can be used to concentrate most proteins, the process reduces the biological activity of many other proteins. Ultra-filtration is another widely used method in volume reduction. However, the loss of purified proteins could be significant, presumably due to nonspecific interactions with the membrane. Our Ni(II)-loaded nanoparticles disperse well in aqueous solution, and therefore significantly smaller elution volume can be used. This advantage eliminates the need of volume reduction and makes it possible to directly use the proteins after purification. Our studies clearly demonstrated that the present magnetic, recyclable nanoparticles are able to bind important His $\times 6$-proteins in native, active conformations with a high capacity and thus show significant advantages over the commercial microbeads. Since the chosen His $\times 6$-proteins have a wide range of molecular weights $(9387.6-74406.8 \mathrm{Da})$ and isoelectric points $(5.43-9.33)$, we do not believe that their binding to the present $\mathrm{Ni}(\mathrm{II})$-loaded nanoparticles are due to simple electrostatic interactions.

\section{Purification of Recombinant His ×6-tagged Proteins from Crude Mammalian Cell Lysate}

Proteins expressed in mammalian cells are usually soluble and active, and therefore extremely useful in studying their physiological significances. The biggest drawback is that their expression levels are very low, making the purification challenging. The nanoparticle platform was previously used for protein purification from $E$. Coli cell lysate,(15) in which proteins are much more easily overexpressed. We investigated whether our NTA-loaded nanoparticles could be used to purify recombinant proteins expressed in mammalian cells. 293T cells were used to express a recombinant His $\times 6-$ UGT protein. The lysate was prepared for purification of $6 \times$ His-UGT protein by the bis-Ni(II)-NTA modified nanoparticles. Figure 4 shows the staining of DL, FT, W3, E1, E2, and nanoparticle fractions and clearly indicates the purification of desired His $\times 6$-tagged protein from the mammalian crude lysate. The elution E1 is significantly cleaner than the direct lysate, with few impurities. These nonspecifically bound impurities are probably due to proteins with many amino acid residues that can coordinate to the immobilized metal ion. Nonetheless, the present nanoparticle system has shown great promise in the purification of His $\times 6$-tagged proteins from crude mammalian cell lysates.

\section{Nonspecific Interactions}

Nonspecific interactions between the protein and nanoparticles do not appear to be significant when the NTA nanoparticles are chelated with Ni(II). Table 1 shows approximately $8.7 \%$ of His $\times 6$-rmES remained on the Ni(II) loaded bis-NTA-modified nanoparticles after elution, slightly higher than that on commercial microbeads. Without the chelation of $\mathrm{Ni}(\mathrm{II})$, His $\times 6$ rmES was found to have a high affinity for the bis-NTA-modified nanoparticle (Figure S5). Densitometry measurements show that more than $45 \%$ of the $6 \times$ His-rmES was present in the 
sum of the washes and elutions, while $39 \%$ of the protein remained on the bis-NTA-modified nanoparticles.

On the other hand, freshly prepared iron oxide nanoparticles (without surface modifications) had little interaction with His $\times 6-\mathrm{rmES}$. Over $70 \%$ of the $10 \mu \mathrm{g}$ of loaded protein was detected in the FT and over $90 \%$ was detected in the sum of the FT and washes. The nanoparticles retained approximately $7 \%$ of the His $\times 6$-rmES after elution, a significant reduction from the $39 \%$ retention of $\mathrm{Ni}(\mathrm{II})$-free bis-NTA-modified nanoparticles. The nonspecific interaction of the rmES to the nanoparticle is thus a result of the surface modifications. To rule out the potential role of residual oleic acid on the nanoparticle surface, we carried out a binding experiment using particles without oleic acid stabilization. Nonspecific interaction was observed for the oleic acid-free nanoparticles as well.

As the ratio of His $\times 6-\mathrm{rmES}(\mu \mathrm{g})$ to bis-Ni(II)-loaded NTA nanoparticle (mg) is increased from 10.2 to 61.3, the amount of non-specifically bound protein appears to remain constant (Figure 5). The specific his-tag binding to Ni(II)-NTA occurs after the full capacity of the nonspecific interaction is reached at a $6 \times$ His-rmES $(\mu \mathrm{g})$ to bis-Ni(II)-loaded NTA nanoparticle $(\mathrm{mg})$ ratio between 10.2 and 15.3. Maximum binding capacity of the nanoparticle via the His $\times 6$-tag appears to have been reached with a His $\times 6$-rmES $(\mu \mathrm{g})$ to bis-Ni(II)-loaded NTA nanoparticle (mg) ratio of 61.3 since some $6 \times$ His-rmES is detectable in the FT.

Various attempts were made to block the nonspecific interaction of the target protein (Figure S6). We first attempted to block the nonspecific binding with BSA. The surface modified nanoparticles were pre-incubated with BSA before the His $\times 6$-rmES binding experiment was performed. Unfortunately, BSA did not effectively block the His $\times 6-\mathrm{rmES}$ nonspecific binding. An attempt of blocking the His $\times 6-$ rmES nonspecific interaction of the nanoparticle with a smaller protein $(\mathrm{His} \times 6-\mathrm{Ub})$ did not seem to result in any noticeable improvement by SDSPAGE analysis.

\section{Surface Density of the Ni-NTA Chelates}

The mono-NTA ligand with two dopamine anchors was synthesized to present monovalency of the Ni(II)-NTA moiety onto the nanoparticle surface. Interestingly, an SDS-PAGE binding assay of the mono-Ni(II)-NTA-modified nanoparticle showed a similarly effective binding with His $\times 6$-rmES (Figure S7). Furthermore, we compared the mono- and bis-Ni(II)-NTA ligand modified nanoparticles by elution with variable imidazole concentrations, and no significant difference was observed. Unlike commercial Ni-NTA beads, the His $\times 6$-rmES could not be eluted from the mono- and bis-Ni(II)-NTA-modified nanoparticles at a $\mathrm{pH}$ as low as 4.0 (without the use of imidazole, Figure S8). These results are suggestive of similar binding affinity of mono- and bis-Ni(II)-NTA-modified nanoparticles, probably a result of high surface coverage of mono-Ni(II)-NTA moieties.

To demonstrate the importance of high surface coverage, we conjugated Ni(II)-NTA to micrometer-sized, carboxy-terminated commercial beads ( $\sim 1.5 \mu \mathrm{m}$ diameter). NTA-lysine was conjugated to the beads via the amide bond using the DCC/NHS coupling protocol. Upon loading with $\mathrm{Ni}(\mathrm{II})$, these beads were found to bind His $\times 6$-rmES as effectively as mono- and bis-Ni(II)-NTA modified nanoparticles (Figure S9). This experiment unambiguously supports the notion that enhanced binding of His $\times 6$-tagged protein can be achieved by taking advantage of the multivalency effect.

\section{CONCLUSIONS}

New bis-nitrilotriacetic acid (NTA) chelates with catechol anchors were synthesized and immobilized on superparamagnetic iron oxide nanoparticles. When loaded with $\mathrm{Ni}(\mathrm{II})$, these 
NTA-immobilized nanoparticles were shown to bind His $\times 6$-tagged proteins in their native, folded conformations with retained activity that commercial microbeads fail to bind under identical conditions. A series of control experiments suggest that the multivalency strategy can be utilized to enhance the binding of His $\times 6$-tagged proteins in their native, folded conformations. We further demonstrated the selective purification of His $\times 6$-tagged proteins from direct cell lysates by using the $\mathrm{Ni}$ (II)-loaded magnetic nanoparticles. The present platform is capable of efficient purification of His $\times 6$-tagged proteins that are expressed at low level in mammalian cells. This work thus presents a novel nanoparticle-based high-capacity protein purification system with shorter incubation times, proportionally large washes, and significantly smaller elution volumes compared to currently available microbeads.

\section{Supplementary Material}

Refer to Web version on PubMed Central for supplementary material.

\section{ACKNOWLEDGMENTS}

We acknowledge NIH (U54-CA119343) for funding this research. We thank Mr. William J. Reiter for taking the TEM images.

\section{References}

1. Porath J, Olin B. Immobilized metal ion affinity adsorption and immobilized metal ion affinity chromatography of biomaterials. Serum protein affinities for gel-immobilized iron and nickel ions. Biochemistry 1983;22:1621-1630. [PubMed: 6849872]

2. Garrett, RH.; Grisham, CM. Biochemistry. 2nd Edition. Saunders College Publishing; Fort Worth: 1999.

3. Porath, J.; Kristiansen, T. Biospecific affinity chromatography and related methods.. In: Neurath, H.; Hill, RL., editors. The Proteins. 3rd edition. 1. Academic Press; New York: 1975. p. 95-178.

4. Hochuli E, Dobeli H, Schacher A. New metal chelate absorbent selective for proteins and peptides containing neighboring histidine residues. J. Chromatogr 1987;411:177-184. [PubMed: 3443622]

5. Braun P, Hu Y, Shen B, Halleck A, Koundinya M, Harlow E, LaBaer J. Proteome-scale purification of human proteins from bacteria. Proc. Natl. Acad. Sci. U.S.A 2002;99:2654-2659. [PubMed: 11880620]

6. Conti M, Falini G, Samorì B. How Strong Is the Coordination Bond between a Histidine Tag and Ni - Nitrilotriacetate? An Experiment of Mechanochemistry on Single Molecules. Angew. Chem. Int. Ed 2000;39:215-218.

7. Kapanidis AN, Ebright YW, Ebright RH. Site-specific incorporation of fluorescent probes into protein: hexahistidine-tag-mediated fluorescent labeling using $\left(\mathrm{Ni}^{2+}\right.$ :nitrilotriacetic acid $) n$-fluorochrome conjugates. J. Am. Chem. Soc 2001;123:12123-12125. [PubMed: 11724636]

8. Lata S, Gavutis M, Tampé R, Piehler J. Specific and Stable Fluorescence Labeling of Histidine-Tagged Proteins for Dissecting Multi-Protein Complex Formation. J. Am. Chem. Soc 2006;128:2365-2372. [PubMed: 16478192]

9. Lata S, Reichel A, Brock R, Tampé R, Piehler J. High-Affinity Adaptors for Switchable Recognition of Histidine-Tagged Proteins. J. Am. Chem. Soc 2005;127:10205-10215. [PubMed: 16028931]

10. Hutshenreiter S, Neumann L, Rädler U, Schmitt L, Tampé R. Metal-Chelating Amino Acids As Building Blocks For Synthetic Receptors Sensing Metal Ions And Histidine-Tagged Proteins. ChemBioChem 2003;4:1340-1344. [PubMed: 14661277]

11. Brook MA, Stan RS. Can, Pat. Appl. CA. 200402309486

12. Sahoo Y, Pizem H, Fried T, Golodnitsky D, Burstein L, Sukenik CN, Markovich G. Alkyl Phosphonate/Phosphate Coating on Magnetite Nanoparticles: A Comparison with Fatty Acids. Langmuir 2001;17:7907-7911.

13. Sun SH, Murray CB, Weller D, Folks L, Moser A. Monodisperse FePt Nanoparticles and Ferromagnetic FePt Nanocrystal Superlattices. Science 2000;287:1989-1992. [PubMed: 10720318] 
14. Park J, An K, Hwang Y, Park J-G, Noh H-J, Kim J-Y, Park J-H, Hwang N-M, Hyeon T. Ultra-largescale syntheses of monodisperse nanocrystals. Nature Mat 2004;3:891-895.

15. Xu C, Xu K, Gu H, Zheng R, Liu H, Zhang X, Guo Z, Xu B. Dopamine as A Robust Anchor to Immobilize Functional Molecules on the Iron Oxide Shell of Magnetic Nanoparticles. J. Am. Chem. Soc 2004;126:9938-9939. [PubMed: 15303865]

16. Bentzen EL, Tomlinson ID, Mason J, Gresch P, Warnement MR, Wright D, Sanders-Bush E, Blakely R, Rosenthal SJ. Surface Modification To Reduce Nonspecific Binding of Quantum Dots in Live Cell Assays. Bioconj. Chem 2005;16:1488-1494.

17. O'Reilly MS, Boehm T, Shing Y, Fukai N, Vasios G, Lane WS, Flynn E, Birkhead JR, Olsen BR, Folkman J. Endostatin: an endogenous inhibitor of angiogenesis and tumor growth. Cell 1997;88:277-285. [PubMed: 9008168]

18. Dhanabal M, Ramchandran R, Waterman MJ, Lu H, Knebelmann B, Segal M, Sukhatme VP. Endostatin induces endothelial cell apoptosis. J. Biol. Chem 1999;274:11721-11726. [PubMed: 10206987] 
<smiles>COC(=O)c1cc(C(=O)NCCc2ccc(OCc3cc(C(=O)Cl)cc(C(=O)Cl)c3)c(OCc3cc(C(=O)Cl)cc(C(=O)Cl)c3)c2)cc(C(=O)OC)c1</smiles><smiles>COC(=O)OCCO</smiles><smiles>CNCCc1ccc(O)c(O)c1</smiles><smiles>CCCC(C(=O)O)N(CC(=O)O)CC(=O)O</smiles><smiles>Cc1cc(C(=O)NCCCCCC(C(=O)OCc2ccccc2)N(CC(=O)OCc2ccccc2)CC(=O)OCc2ccccc2COC(C)(C)C)cc(C(=O)NCCc2ccc(OCc3ccccc3)c(OCc3ccccc3)c2)c1</smiles>

Scheme 1. 
<smiles>COC(=O)c1cc(C(=O)NCCc2ccc(OCc3ccccc3)c(OCc3ccccc3)c2)cc(C(=O)NCCc2ccc(OCc3ccccc3)c(OCc3ccccc3)c2)c1</smiles>

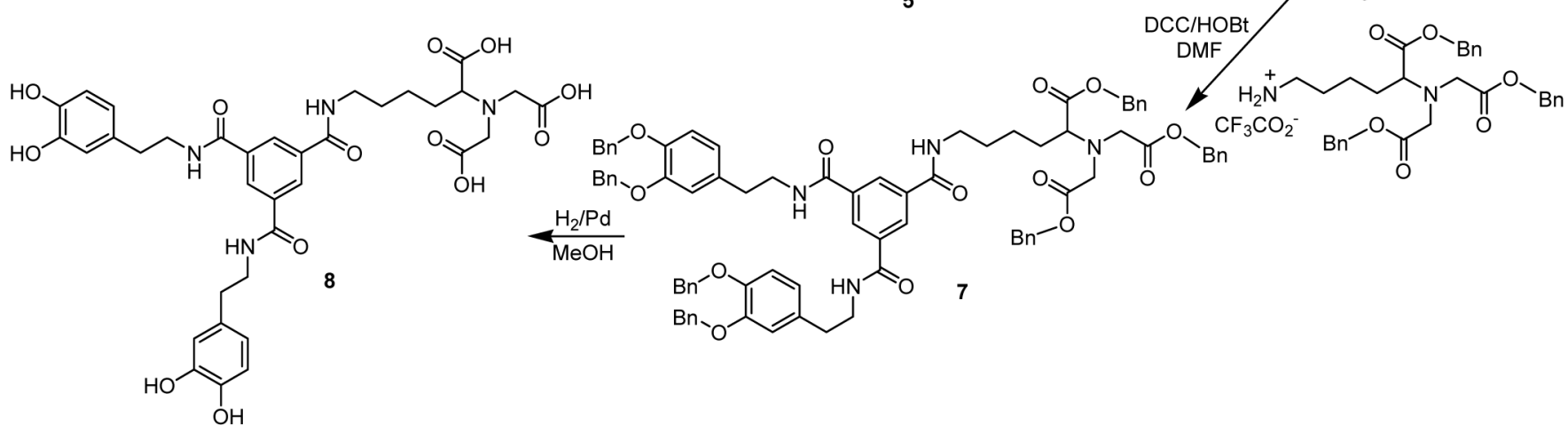

\section{Scheme 2.}






Scheme 3. 
A)

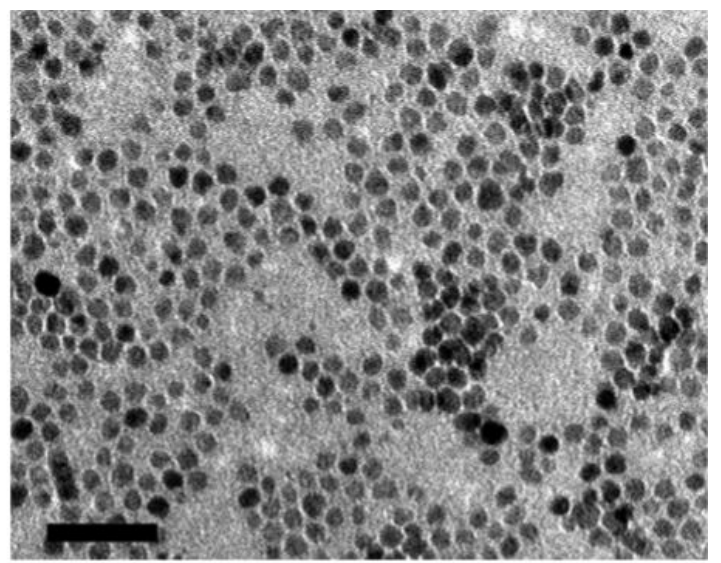

B)
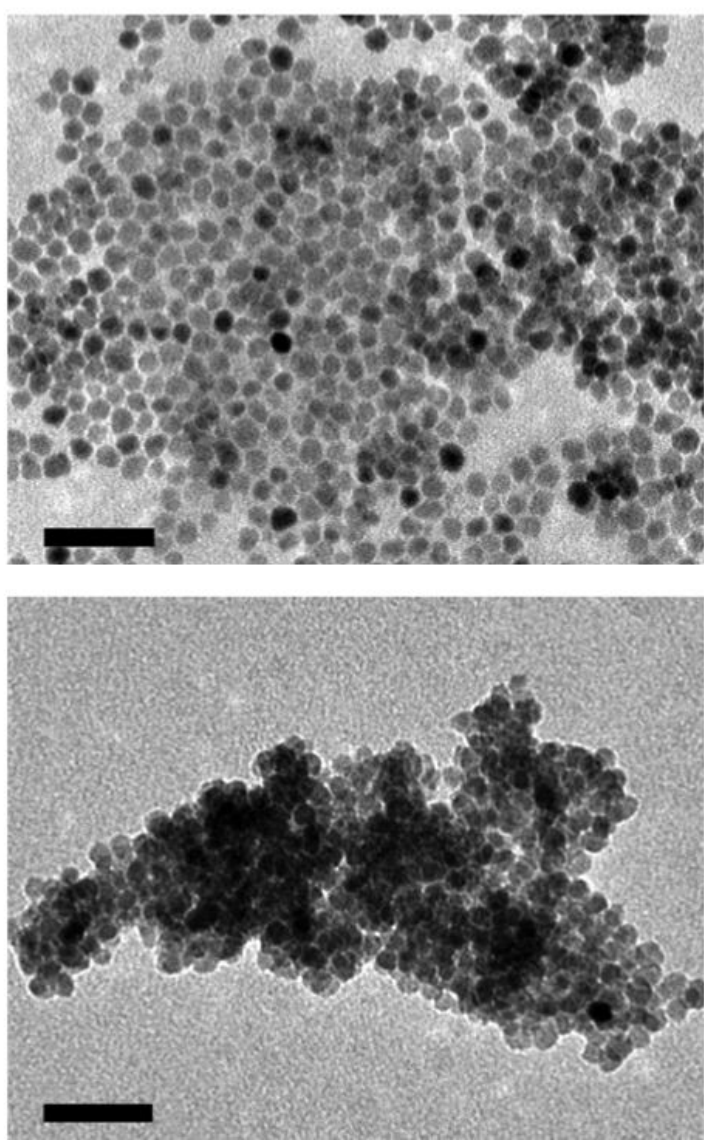
D)

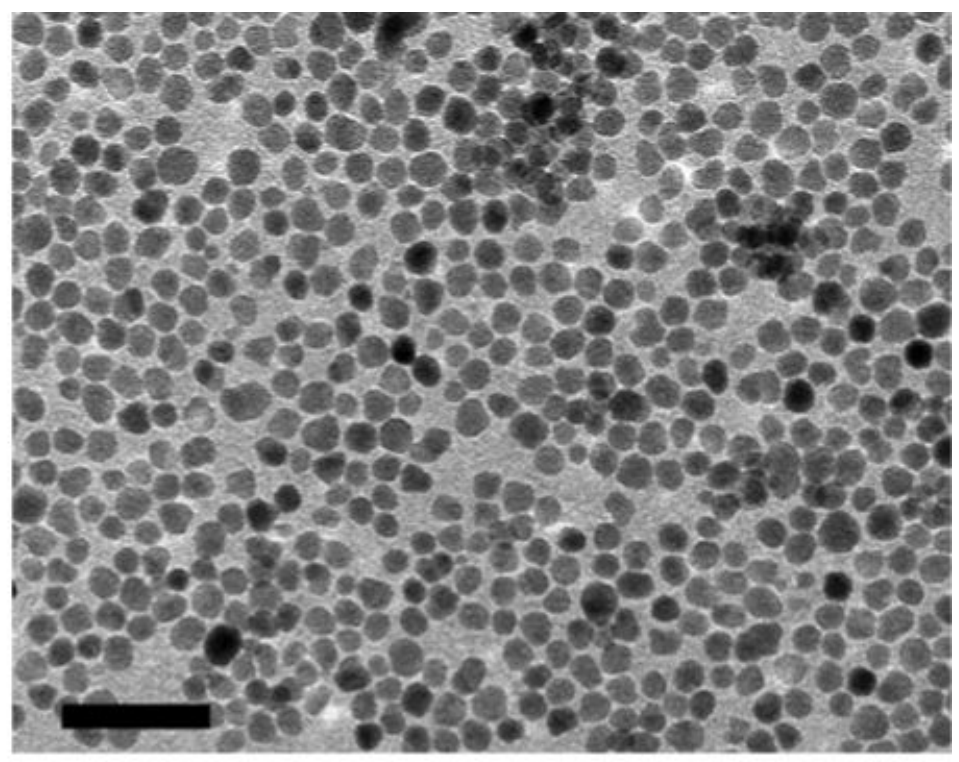

E)

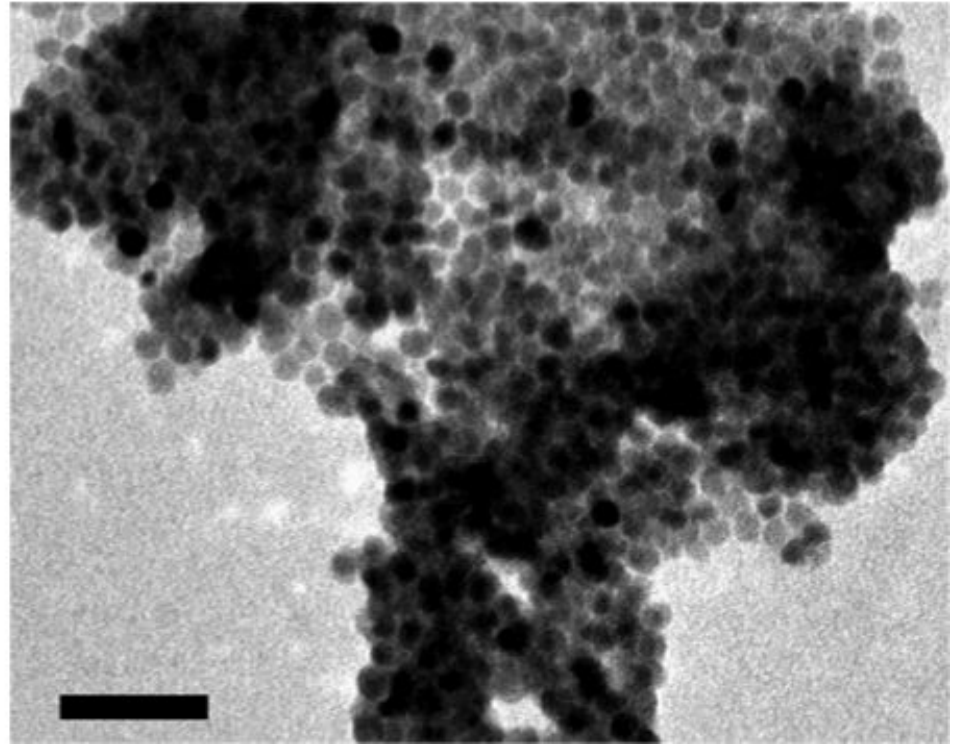

Figure 1.

TEM images of monodisperse iron oxide nanoparticles ( $10 \mathrm{~nm}$ in diameter): A) Prepared by thermal decomposition and stabilized with oleic acid; B) Modified with bis-NTA ligand; C) $\mathrm{Ni}$ (II)-loaded bis-NTA nanoparticle; D) Modified with mono-NTA ligand; E) Ni(II)-loaded mono-NTA nanoparticle. The scale bar is $50 \mathrm{~nm}$. 


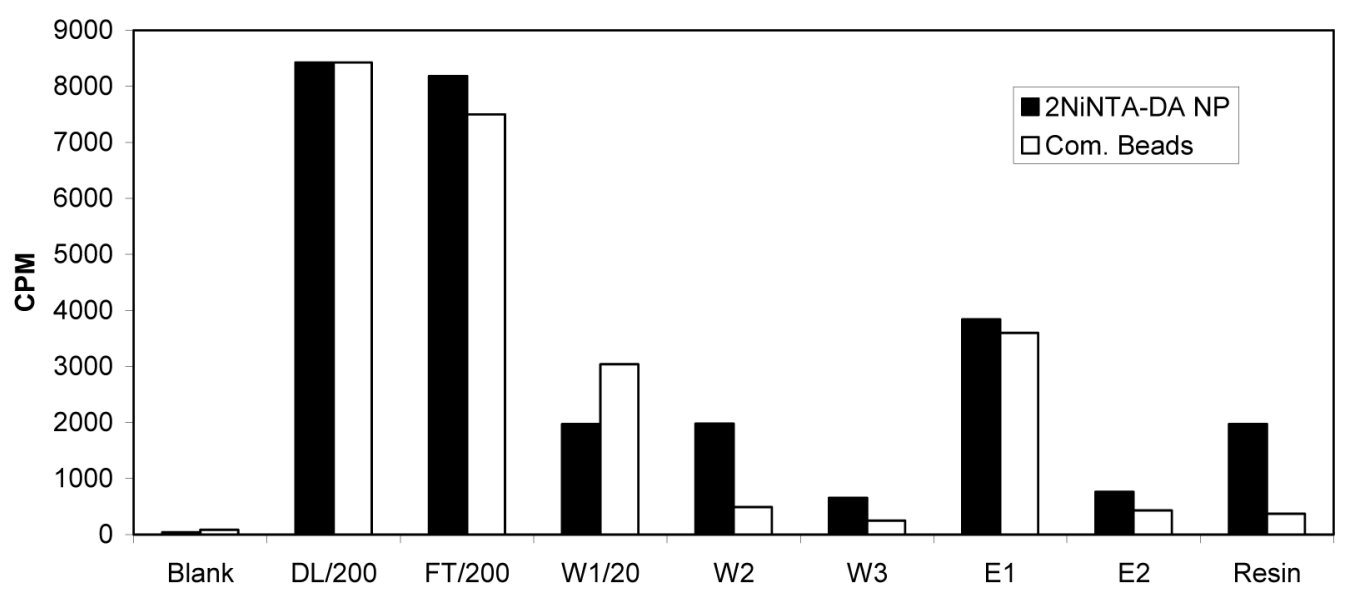

Figure 2.

Graphical representation of $\left[{ }^{35} \mathrm{~S}\right]$-labeled His $\times 6-$ GMAP-210 binding scintillation counting assay for bis-Ni-NTA nanoparticles (solid bars) and commercial Ni-NTA agarose beads (open bars). Fractions collected and radioactivity quantified in counts per minute (CPM), DL = Direct Lysate, FT = Flow Through, W1 = Wash 1, W2 = Wash 2, W3 = Wash 3, E1 = Elution 1, E2 $=$ Elution 2 . 
(A)

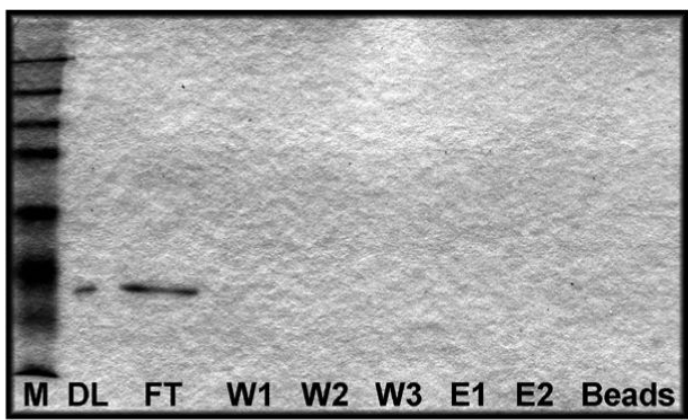

(B)

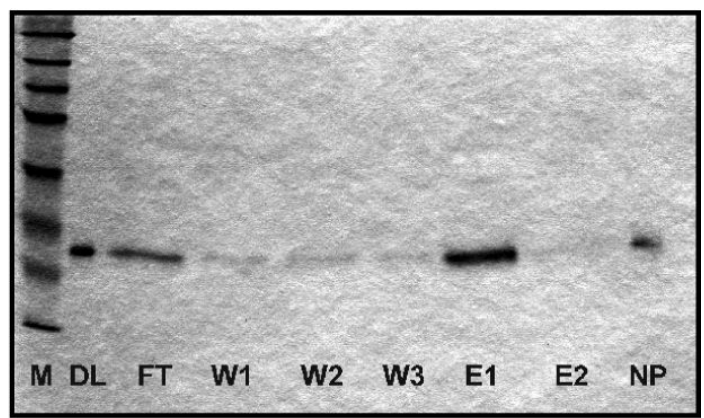

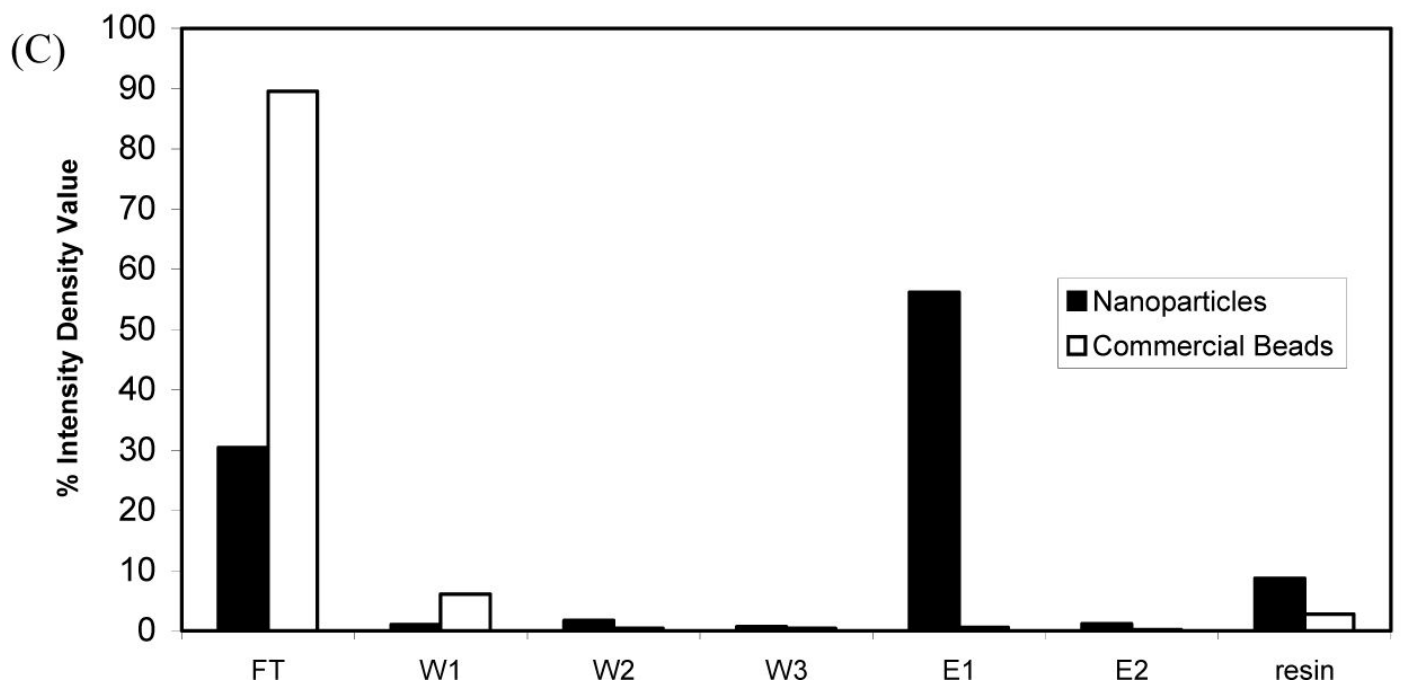

Figure 3.

Binding assay of His $\times 6$-rmES: (A) Commercial magnetic agarose beads (Qiagen): no protein was bound to the bead or eluted by imidazole. Most of the protein was washed away unbound in the FT. (B) Bis-Ni-NTA NPs: His $\times 6$-tag protein was bound and a majority was eluted from the nanoparticles by imidazole. (C) Graphical representation of densitometry quantification of SDS-PAGE gels. 


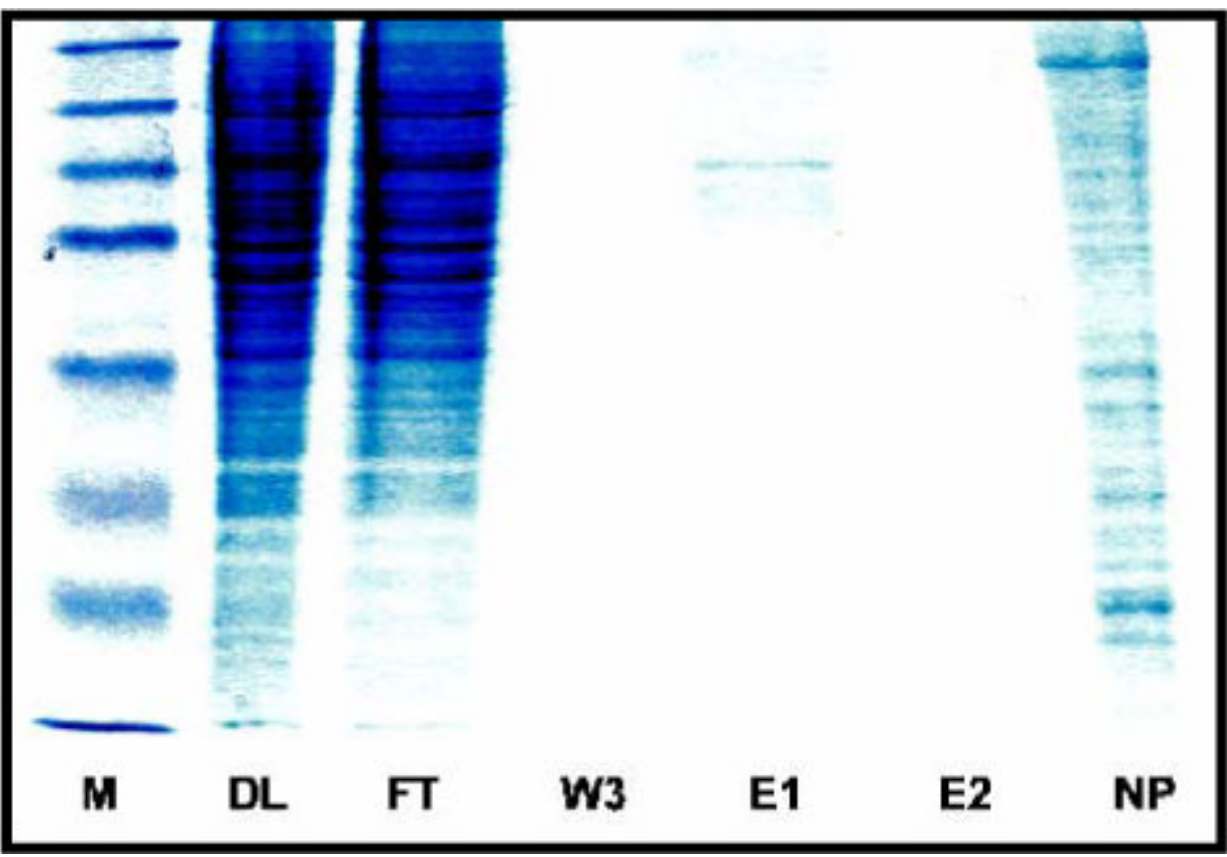

Figure 4.

Mammalian Cell Lysate Fractionation. SDS-PAGE (12.5\% separation gel) results of flagHis $\times 6-U G T$ expressed in 293 T cells showing marker (M), direct lysate (DL, 10\% dilution), flow through (FT, 10\%), wash 3 (W3), elution 1 (E1), elution 2 (E2), and protein residue on nanoparticle (NP). 


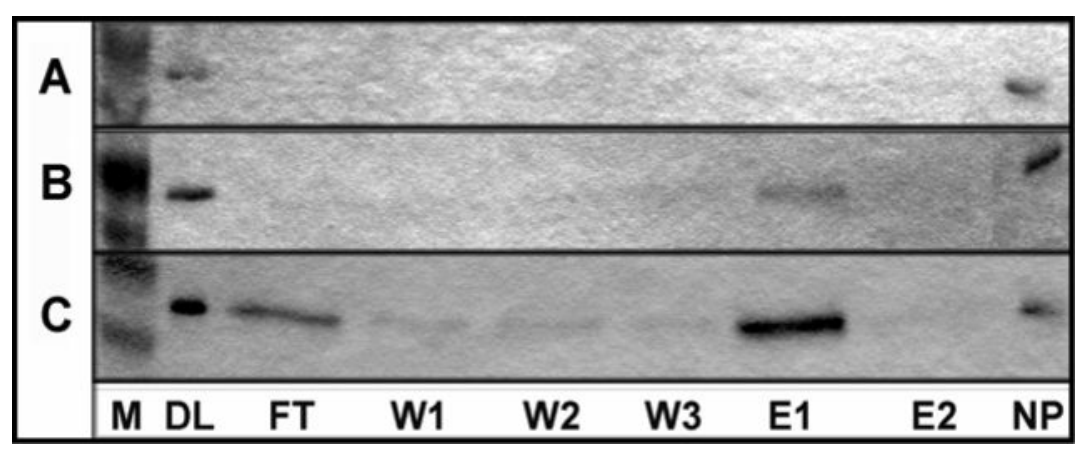

Figure 5.

Preference toward nonspecific interaction before his-tag-Ni-NTA interaction demonstrated through increasing ratios of $6 \times$ His-rmES protein $(\mu \mathrm{g})$ to bis-Ni-NTA nanoparticle $(\mathrm{mg}) \mathrm{A}$ : 10.2, B: 15.3, C: 61.3. ( M = Marker, FT = Flow Through, W1 = Wash 1, W2= Wash 2, Wash $3=\mathrm{W} 3, \mathrm{E} 1=$ Elution 1, E2 = Elution 2, NP = protein bound nonspecifically to nanoparticle.) 


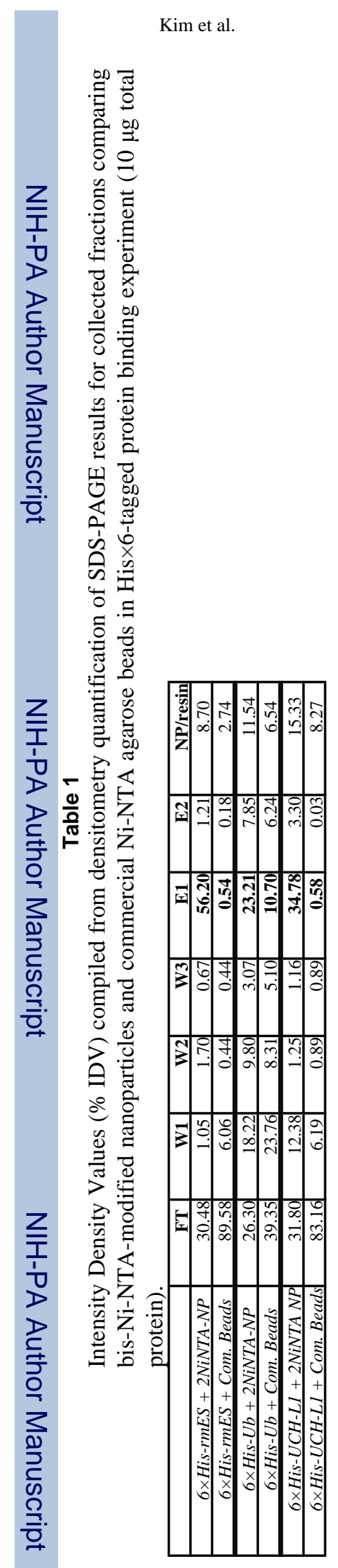

Page 22

클

घี

0

으

\%

(4)

$\overline{0}$

4

可

뒹

1

会量

ธี

踏

艺

대요

. ํㅗㄹ 